\title{
Epizootiology, pathology, and ultrastructure of the myxosporean associated with parasitic encephalitis of farmed Atlantic salmon Salmo salar in Ireland
}

\author{
S. Frasca Jr ${ }^{1, *}$, S. L. Poynton ${ }^{2}$, A. B. West ${ }^{3}$, H. J. Van Kruiningen ${ }^{1}$ \\ ${ }^{1}$ Northeastern Research Center for Wildlife Diseases, Department of Pathobiology, U-89, University of Connecticut, \\ 61 North Eagleville Road, Storrs, Connecticut 06269-3089, USA \\ ${ }^{2}$ Division of Comparative Medicine, Johns Hopkins University School of Medicine, 720 Rutland Avenue, Baltimore, \\ Maryland 21205-2196, USA \\ ${ }^{3}$ Department of Pathology, University of Texas Medical Branch, 301 University Boulevard, Galveston, Texas 77555-0588, USA
}

\begin{abstract}
In 1995 at a sea-farm in Ireland, Atlantic salmon Salmo salar smolts were introduced in the spring and autumn into 2 marine rearing sites, one with and one without recent histories of neurologic disease and mass mortality believed to be due to parasitic encephalitis. In order to monitor disease, determine the onset and anatomic distribution of parasites and encephalitis, and determine the ultrastructure and identity of the parasite, randomly selected smolts were necropsied from both sites at intervals of 1 to $3 \mathrm{~d}$ for periods of 1 to $2 \mathrm{mo}$, and clinical signs and cumulative mortalities were monitored. The prevalences of parasites and encephalitis were assessed by light microscopy, and sections of brain were examined by transmission electron microscopy. No clinical signs of neurologic disease were observed, but parasites and encephalitis were detected in smolts from both sites, with prevalences of each that were significantly greater in smolts from the site with recent disease. Based on light microscopy, the parasite was first detected in smolts sampled at $26 \mathrm{~d}$ post-introduction. Parasites were detected with significantly greater frequency in the optic tectum of the mesencephalon than in the diencephalon, metencephalon, and myelencephalon, and were not detected in the telencephalon. Foci of non-suppurative encephalitis were detected with significantly greater frequency in the myelencephalon than in each of the other 4 anatomic subdivisions. In each anatomic subdivision the prevalence of encephalitis was significantly greater than that of parasitic infection. The ultrastructure of the parasite was consistent with that of a histozoic presporogonic multicellular developmental stage of a myxosporean, characterized by intercellular branching tubular structures containing generative cells arranged individually or in cellin-cell doublets. Parasitic stages were located between bundles of axons, with compression of axons along segments of their plasmalemma. No mature spores were detected.
\end{abstract}

KEY WORDS: Atlantic salmon · Brain · Myxosporean · Parasitic encephalitis · Ultrastructure

\section{INTRODUCTION}

The morbidities and mortalities caused by parasitic infections comprise a considerable portion of the annual 3 billion dollar losses to disease that the aquaculture industry incurs worldwide (Brown 1996). In North America and Europe, spore-forming parasites are agents of salmonid diseases that significantly impact production. Most notable among these para-

•E-mail: sfrasca@canr1.cag.uconn.edu sites are the myxosporeans, such as Myxobolus cerebralis and Ceratomyxa shasta (Lom \& Dykova 1995), the microsporidians, such as Loma salmonae and Enterocytozoon salmonis (Dykova 1995), and the Dermocystidium spp. (McVicar \& Wootten 1980) and Dermocystidium-like protozoa (Hedrick et al. 1989).

In 1992, 1993 and 1994, an unclassified parasite was detected in association with encephalitis and mass mortality of netpen-reared Atlantic salmon Salmo salar smolts at a sea-farm in Ireland (Rodger et al. 1995. Scullion et al. 1996). During epizootics of parasitic 
encephalitis, neurologic signs and mortalities began 6 to $8 \mathrm{wk}$ after transfer to sea, and affected smolts displayed circling or gyrating swimming, inappropriate postures in the water column, stacking on pen floors, and periods of apparent unconsciousness, after which affected fish subsequently regained their normal swimming pattern (Rodger et al. 1995). Foci of parasites with and without attendant encephalitis were detected in histologic sections of brain and spinal cord 1 to $2 \mathrm{wk}$ before the onset of clinical signs (Rodger et al. 1995). In histologic section, parasites appeared either as strings or clusters of circular or ovoid organisms, approximately 5 to $9 \mu \mathrm{m}$ in diameter, frequently surrounded by a membrane. They were tentatively identified as the extrasporogonic stage of a myxosporean by Rodger et al. (1995). Bacteriologic, virologic, and toxicologic tests on affected smolts yielded no significant findings (Scullion et al. 1996).

Several myxosporean species have previously been reported to infect the central nervous system of salmonids. Myxobolus neurobius Schuberg \& Schroder, 1905 is common in Eurasian Salmo trutta m. fario, Thy mallus thymallus and other salmonids (GonzalesLanza \& Alvarez-Pellitero 1984), and has been reported in Salmo salar and Salvelinus alpinus from Newfoundland (Maloney et al. 1991). Aggregates of developmental plasmodia and spores elicit atrophy of white matter of the brain and spinal cord (Lom \& Dykova 1992). Mature spores of Myxobolus kisutchi Yasutake \& Wood, 1957 have been identified in the spinal cord of juvenile Oncorhynchus kisutch in Pacific Northwest America (Yasutake \& Wood 1957), and cysts containing mature spores of $M$. kisutchi have also been reported from the midbrain of fingerling spring chinook Oncorhynchus tshawytscha (Wyatt 1978). Spores of Myxobolus arcticus Pugachev \& Khokhlov, 1979 were identified in the spinal cord and brain of species of Salvelinus (e.g. S. malma) and Oncorhynchus (e.g O. nerka) (Pugachev \& Khokhlov 1979, Rutherford et al. 1992). In sharp contrast to the mass mortalities associated with parasitic encephalitis reported by Rodger et al. (1995) and Scullion et al. (1996), none of these myxosporean species is known to cause serious disease, according to Lom \& Dykova (1995).

Improved characterization of the parasite infecting the brains of farmed salmon smolts, as reported by Rodger et al. (1995) and Scullion et al. (1996), is required to understand its association with encephalitis and mass mortality. A study of Atlantic salmon Salmo salar smolts was therefore conducted to monitor clinical signs of neurologic disease, to determine the onset and anatomical distribution of parasitic infection and encephalitis, and to describe the ultrastructure of the parasite in order to detail morphologic evidence for its taxonomic identification.

\section{METHODS}

Study sites. Studies were conducted at the same Atlantic salmon sea-farm in Northwest Ireland that had experienced mass mortalities due to parasitic encephalitis in 1992 to 1994 , as reported by Rodger et al. (1995) and Scullion et al. (1996). Established in 1980, the farm annually produces 3000 tonnes of fish and has maintained an excellent record of disease monitoring, control, and feed conversion. Fry are reared in net-covered, open-top, fiberglass tanks supplied with river water in parallel, and are fed commercial pelleted rations. Fish are reared at the freshwater hatcheries for approximately 1 yr until they smoltify, and are then transferred to marine sites where they are grown in floating netpens for at least $18 \mathrm{mo}$.

Two marine sites, designated $\mathrm{A}$ and $\mathrm{C}$ by Rodger et al. (1995), were investigated in this present study. Marine rearing site A has a history of the disease and is located in an exposed sea lough approximately 25 miles long and 2 miles wide $(1$ mile $=1.6 \mathrm{~km})$. At the location of the netpens, which hold multiple year classes of salmon, this site receives high volume exchanges of Atlantic waters from the north, with tides averaging $15 \mathrm{ft}$ (ca $4.5 \mathrm{~m}$ ) and strong reversing tidal currents that generate increased suspended solids. An urban sewage outflow and a textile factory discharge into this body of water at points more than 2 miles distant from this site. Annually from February to April, up to 12 factory fishing ships anchor south of Site A for short periods and discharge waste materials and viscera from processed fish. Two rivers flow into the south end of this bay, each of which has a run of wild Atlantic salmon, and there is a small rainbow trout Oncorhynchus mykiss hatchery on one of these rivers. Mussel farming from wild caught mussel spat Mytilus edulis was begun in this bay in 1992 and takes place more than 1 mile from site $\mathrm{A}$. In 1995, the mean water temperature ranged from $6.5^{\circ} \mathrm{C}$ in April to $15.5^{\circ} \mathrm{C}$ in August and from $11.8^{\circ} \mathrm{C}$ in October to $7.6^{\circ} \mathrm{C}$ in $\mathrm{De}$ cember. No thermoclines occur in this lough.

Marine rearing site $C$ has no history of the disease and is located in a separate sea lough some 12 miles long and one-half mile wide. Netpens at 2 distinct locations in this lough were sampled, and all hold single year classes only. This site is much less exposed to adverse tides and weather conditions from the north; no commercial sources of pollution are present, and there is no run of wild Atlantic salmon through this lough, although anadromous trout Salmo trutta are numerous. In 1995, the mean water temperature ranged from $7.1^{\circ} \mathrm{C}$ in April to $16.0^{\circ} \mathrm{C}$ in August and from $12.4^{\circ} \mathrm{C}$ in October to $6.9^{\circ} \mathrm{C}$ in December. The temperature is similar at all netpen locations in this lough. At 
both site $A$ and site $C$, the salinity ranges from 32 parts per thousand (ppt) to $35 \mathrm{ppt}$, averaging $33 \mathrm{ppt}$.

Routine health surveillance. Health assessments of smolts were performed monthly by staff at the seafarm, and routinely consisted of gross necropsy, histopathology, and bacteriology. For smolts of the 2 studies, there was a daily evaluation of clinical signs and cumulative mortalities, together with weekly gross necropsy, histopathology, and bacteriology. Tissue sections of skin, muscle, gill, coelomic viscera, spinal cord and brain were examined histologically, and bacteriologic tests consisted of swabs of mid-kidney inoculated onto tryptic soya agar (TSA), TSA supplemented with $1 \% \mathrm{NaCl}$, cytophaga agar, and bacterial kidney disease media (BKDM). Virologic testing was conducted only in the event that clinical signs of neurologic disease were detected, consisted of inoculations of cellfree extracts of pooled tissues onto bluegill fry (BF-2) and epithelioma papullosum cyprino (EPC) cell lines, and was performed by a private fish health laboratory contracted independently by the sea-farm.

Schedule of introductions and sampling protocol. Two studies were done, one in summer (July to August) to determine the prevalence of the parasite and encephalitis at site $C$, the site without the disease, and one in winter (November to January) to determine the time course of infection and encephalitis, and to compare events at historically affected $(A)$ and unaffected (C) sites. Separate introductions to the marine rearing sites were performed in conjunction with the scheduled management practices of the farm, and sampling protocols focused on the period shortly after transfer to sea as this was the only time when neurologic disease and mortality had been previously described (Rodger et al. 1995, Scullion et al. 1996). Smolts originated from a freshwater hatchery with no history of neurologic disease or record of parasitic encephalitis

On April 11, 1995, 100000 smolts were introduced to 1 netpen location within site $C$, and commencing on July $26,1995,6$ randomly selected smolts were necropsied daily for $5 \mathrm{~d}$ and every third day thereafter until August 17, 1995.

On October 25, 1995, 50000 smolts were introduced to a second netpen location within site $C$, and on November 1, 1995, 17500 smolts were introduced to site A. Following the latter introduction, 6 randomly selected smolts were necropsied from each site on November 1, daily on November 2 to 5, and every third day thereafter until January 15, 1996.

Light microscopy. All sampled fish were taken promptly to the farm laboratory for necropsy. Brains of necropsied fish were immersion-fixed in a cold solution of $1.5 \%$ paraformaldehyde, $1.5 \%$ glutaraldehyde, and $3 \mathrm{mM} \mathrm{MgCl}_{2}$ in $0.1 \mathrm{M}$ sodium cacodylate buffer ( $\mathrm{pH} \mathrm{7.3)} \mathrm{for} 12$ to $24 \mathrm{~h}$, and then washed and stored in $0.1 \mathrm{M}$ sodium cacodylate buffer ( $\mathrm{pH} 7.3$ ). To generate representative samples of the telencephalon, diencephalon, mesencephalon, metencephalon, and myelencephalon, so that the distributions of parasites and encephalitis could be determined, fixed brains were randomly assigned to 1 of 2 patterns of dissection, and were sliced either sagittally (i.e. passing dorsoventrally through the median longitudinal axis) or transversely (i.e. passing dorsoventrally perpendicular to the median longitudinal axis). For brains sliced transversely, first slices were made at the optic chiasma, the pituitary gland, and the rostral and caudal medulla oblongata; then, the resultant pieces were bisected to produce slices of the olfactory lobe, rostral hypothalamus and optic tectum, caudal hypothalamus and optic tectum, cerebellum and rostral medulla oblongata, and caudal medulla oblongata. Neuroanatomic landmarks and locations were based on descriptions of the neuroanatomy of striped bass Morone saxatilis by Groman (1982) and rainbow trout Oncorhynchus mykiss by Yasutake \& Wales (1983). Slices of brain were routinely processed for paraffin-embedding, sectioned at $3 \mu \mathrm{m}$, and stained with hematoxylin, eosin and luxol fast blue, to highlight myelin (Carson 1987).

For each brain, each of the 5 major anatomic subdivisions was examined. Parasites and encephalitis were recorded as present or absent. If present, foci were enumerated, and the severity of encephalitis was rated as mild, moderate, or severe. Observations were made by light microscopy at $100 \times$ total magnification, with examination of all available fields of view within the histologic sections provided of each brain.

Transmission electron microscopy. Whenever foci of parasites were detected in paraffin sections, equivalent anatomic regions were dissected from fixed slices of the same brain that had been stored in $0.1 \mathrm{M}$ sodium cacodylate buffer. Dissected tissues were fixed for an additional $4 \mathrm{~h}$ in $2 \%$ paraformaldehyde and $2 \%$ glutaraldehyde in $0.1 \mathrm{M}$ sodium cacodylate buffer ( $\mathrm{pH} 7.3$ ), washed in $0.1 \mathrm{M}$ sodium cacodylate buffer ( $\mathrm{pH} 7.3$ ), and post-fixed in $1 \%$ osmium tetroxide in $0.1 \mathrm{M}$ sodium cacodylate buffer ( $\mathrm{pH} 7.3$ ) for $2 \mathrm{~h}$. Post-fixed tissues were stained en bloc with $1 \%$ uranyl acetate in $0.1 \mathrm{M}$ maleate buffer ( $\mathrm{pH}$ 5.2), dehydrated using an ascending gradient of ethanol, and embedded in Poly/Bed 812 resin (Polysciences, Warrington, Pennsylvania, USA). Blocks were polymerized at $60^{\circ} \mathrm{C}$. Both semi-thin and ultra-thin sections were prepared using a Reichert Ultracut S ultramicrotome. Semi-thin $(1 \mu \mathrm{m})$ tissue sections were stained with toluidine blue and basic fuschin, and examined by light microscopy for foci of interest. Ultra-thin tissue sections were taken at silver to gold interference colors, stained with $0.4 \%$ lead citrate, and examined using a Philips CM 100 electron microscope. Descriptions of the parasite 
followed the recommendations of Lom \& Arthur (1989), and terminology followed that of Lom \& Dykova (1992) and Moser \& Kent (1994). The usage of ccological terms followed the definitions of Margolis et al. (1982).

Data analysis. In calculations of prevalence of infection and encephalitis at different sites and times, only data from complete brains (i.e. specimens consisting of histological sections of all 5 subdivisions) were used in order to avoid sample bias. For determinations of distributions of parasites and encephalitis in the $5 \mathrm{sub}$ divisions within brains, all samples were used. Chisquare testing was used to determine if the prevalence of parasites or encephalitis was significantly different between populations of smolts at the 2 sites, and whether foci of parasites or encephalitis were randomly distributed among the 5 anatomic subdivisions of the brain. Differences were considered significant if $p$ was less than 0.05 .

\section{RESULTS}

\section{Epizootiology}

During the periods of the 2 studies, no clinical signs of neurologic disease were observed. Six to eight weeks after introduction, lesions consistent with phagocytolytic syndrome (Palmer et al. 1992) were identified in a minority of smolts from the winter study; bacteriologic and virologic tests yielded no significant findings, no lesions were detected histologically in brains, and cumulative mortalities were within normal production limits for the sea-farm (less than $4 \%$ ).

Brains from 352 Atlantic salmon smolts were examined, and consisted of 57 from the summer study (site C), and 295 from the winter study (133 site A and 162 site C). Of these 352 fish, 11 (9 site A and 2 site C) were infected with the parasite, and a total of $206 \mathrm{com}$ plete brains (57 site $\mathrm{C}$ in summer, 68 site $\mathrm{A}$ and 81 site $C$ in winter) were included in the overall examination.
The prevalence of infection in winter was significantly greater at site A, 7\% (5/68), than at site C, $0 \%$ $(0 / 81)$. The parasite was first detceted at site $A$ on Day 26 post-introduction, and then intermittently until Day 76, the final day of sampling. Although no parasites were detected at site $C$ during the winter study, parasites were detected at site $C$ during the summer study (i.e. smolts introduced in April), and the prevalence of infection in summer at site C was $4 \%(2 / 57)$.

The prevalence of encephalitis in winter was significantly greater at site A, $34 \%(23 / 68)$, than at site C, $14 \%(11 / 81)$. The earliest detection of encephalitis was at Day 4 post-introduction at site $A$ and Day 16 post-

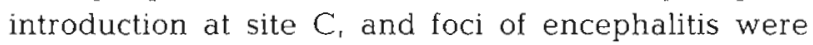
detected throughout the $76 \mathrm{~d}$ study period at both sites. In smolts introduced in April to site $C$ and sampled during the summer study, the prevalence of encephalitis was $30 \%(17 / 57)$, and encephalitic foci were detected intermittently throughout the period of study.

\section{Histopathology}

Parasites were unevenly distributed in brains, were most frequently encountered in the mesencephalon $(2.4 \%)$, less frequently in the diencephalon $(0.3 \%)$. metencephalon $(0.3 \%)$, and myelencephalon $(0.3 \%)$, and were not detected in the telencephalon (Table 1). The frequency of detection in the mesencephalon was significantly greater than in each of the other subdivisions. Within the mesencephalon, parasites were most frequently encountered in the lamina of the optic tectum. Parasites were identified in grey matter of the hypothalamus of the diencephalon, the molecular layer of the cerebellum of the metencephalon, and white matter of the medulla of the myelencephalon. The density of infection was usually one focus of infection per subdivision of the brain, and usually parasites were detected in only one subdivision of each infected brain.

Table 1 Salmo salar. Distributions of parasites (p) and encephalitis (e) in the 5 anatomic subdivisions of the brains of Atlantic salmon smolts. Data are the number of subdivisions affected, followed by the total number of subdivisions examined ( $t$ ). Note that the frequency of encephalitis was significantly greater than the frequency of parasitic infection for each anatomic subdivision

\begin{tabular}{|c|c|c|c|c|c|c|}
\hline Study & Site & $\begin{array}{l}\text { Telencephalon } \\
(p, e, t)\end{array}$ & $\begin{array}{l}\text { Diencephalon } \\
\qquad(p, e, t)\end{array}$ & $\begin{array}{c}\text { Mesencephalon } \\
\qquad(p, e, t)\end{array}$ & $\begin{array}{l}\text { Metencephalon } \\
(p, e, t)\end{array}$ & $\begin{array}{l}\text { Myelencephalon } \\
(p, e, t)\end{array}$ \\
\hline \multirow{4}{*}{$\begin{array}{l}\text { Summer } \\
\text { Winter }\end{array}$} & Site $C$ & $0,2,57$ & $0,9.57$ & $2,7,57$ & $0,2,57$ & $0,9,57$ \\
\hline & Site A & $0,2,72$ & $1,9,118$ & $6,15,126$ & $1,9,128$ & $1,28,127$ \\
\hline & Site C & $0,0,85$ & $0,5,147$ & $0,6,151$ & $0,6,157$ & $0,15,145$ \\
\hline & Total & $0,4,214$ & $1,23,322$ & $8,28,334$ & $1,17,342$ & $1,52,329$ \\
\hline \multirow{2}{*}{\multicolumn{2}{|c|}{$\begin{array}{l}\% \text { infected with parasite } \\
\% \text { encephalitis }\end{array}$}} & $0.0(0 / 214)$ & $0.3(1 / 322)$ & $2.4(8 / 334)^{\circ}$ & $0.3(1 / 342)$ & $0.3(1 / 329)$ \\
\hline & & $1.9(4 / 214)$ & $71(23 / 322)$ & $8.4(28 / 334)$ & $5.0(17 / 342)$ & $15.8(52 / 329)^{\circ}$ \\
\hline
\end{tabular}


Encephalitis was detected in each of the anatomic subdivisions of the brain, and was most frequently detected in the myelencephalon $(15.8 \%)$, less frequently in the mesencephalon (8.4\%), diencephalon $(7.1 \%)$, and metencephalon $(5.0 \%)$, and rarely in the telencephalon $(1.9 \%)$ (Table 1$)$. The frequency of encephalitis in the myelencephalon was significantly greater than in each of the other subdivisions, and the frequency of encephalitis was significantly greater than that of parasitic infection in each subdivision. One to multiple encephalitic foci were detected per subdivision, and encephalitic foci were detected in one or more subdivisions per brain. During the winter study at site $A$, the number and severity of encephalitic foci increased after the mid-point of the sampling period (approximately Day 38 post-introduction). The lower prevalence of encephalitis at site $C$ precluded detection of temporal change.

Foci of encephalitis were non-suppurative, multifocal, and mild to severe. Most foci were mild and consisted of loose infiltrations of perivascular neuropil by small numbers of glial cells, macrophages, and lymphocytes (Fig 1A.), while occasional foci were severe and consisted of nodular infiltrates of larger numbers of densely packed glial cells and macrophages (Fig. 1B). The most severe encephalitic foci were present in sections of the myelencephalon in smolts from both sites. Parasites were observed both with and without infiltrates of glial cells and macrophages. There were inflammatory infiltrates wherein no parasites were detected.

\section{Morphology and ultrastructure of the parasite}

In histologic section, parasites from the 1995 summer and winter studies were multicellular developmental stages morphologically identical to those detected in smolts from previous years. Stages were irregularly shaped, straight or curved tubules with frequent, wideangle, club-shaped branching in longitudinal section (Fig. 2A), and were oval to round in transverse section (Fig. 2B). They ranged in length from 10 to $100 \mu \mathrm{m}$, with widths typically of 5 to $15 \mu \mathrm{m}$, occasionally reaching $30 \mu \mathrm{m}$. Stages contained multiple cells arranged into strings or clusters, bound by a thin outer membrane, and occasional transverse sections contained 1 or 2 cells (Fig. 2A). The cells were ovoid, uninucleate, and 2 to $5 \mu \mathrm{m}$ in length, with scant eosinophilic cytoplasm (Fig. 2).

Based on transmission electron microscopy, parasitic developmental stages were intercellular, located between bundles of small and medium diameter nerve fibers (Fig. 3). Along segments of the plasmalemma of the parasite, there was compression of surrounding nerve fibers or stacking of myelinated and unmyelinated axonal membranes, and the plasmalemma was deeply invaginated by nerve fibers at multiple loci (Fig. 4)

Parasitic developmental stages were bound by an undulating cytoplasmic membrane with multiple pinocytotic channels, and the cytoplasm of the primary cell was differentiated into an ectoplasm and endoplasm
A

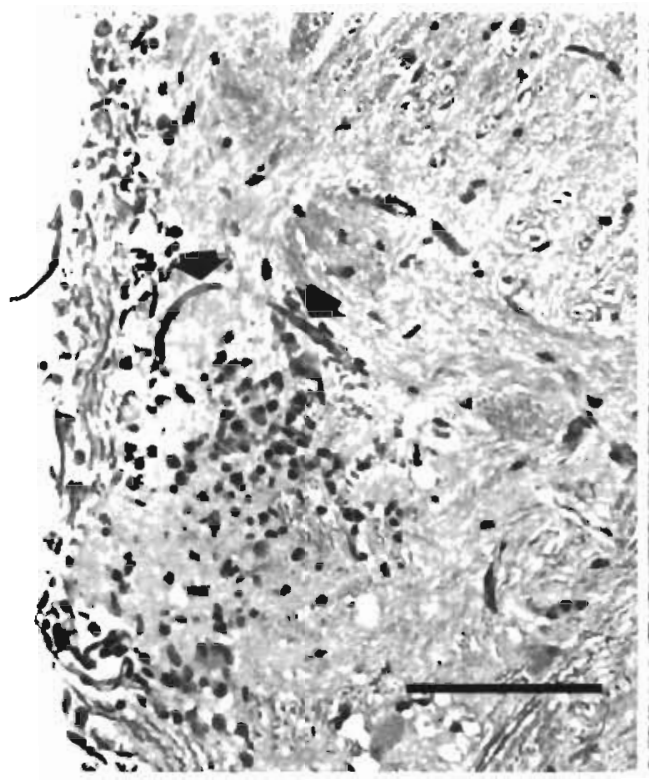

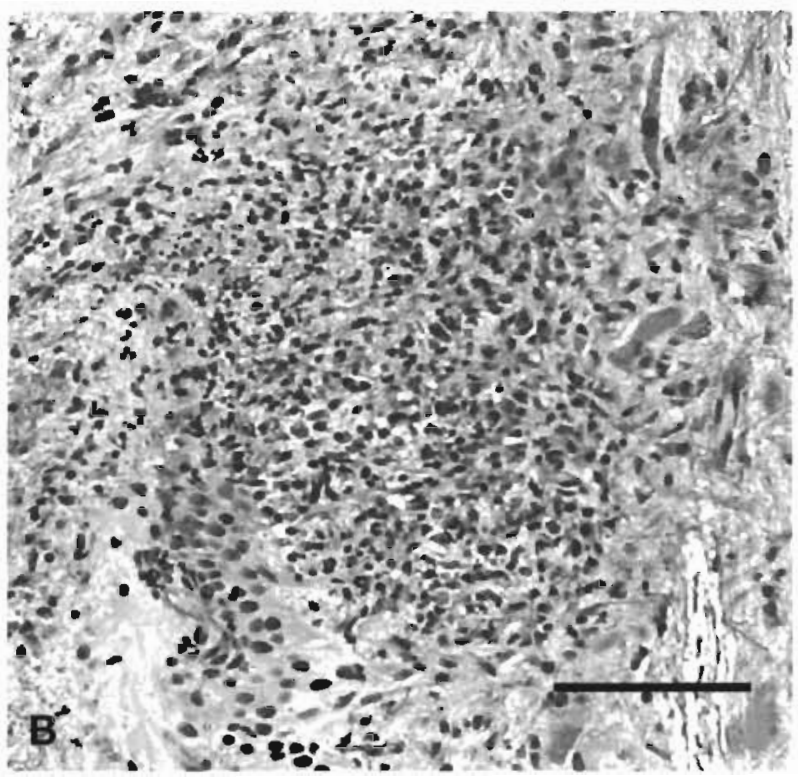

Fig. 1. Salmo salar. Foci of encephalitis representing the range of severity observed. (A) A focus of mild encephalitis consisting of loose infiltrates of small numbers of glial cells, macrophages, and lymphocytes is present in the neuropil adjacent to capillaries (arrows). Atlantic salmon smolt, myelencephalon, medulla oblongata. Hematoxylin, eosin, and luxol fast blue. Scale bar = $100 \mu \mathrm{m}$. (B) A focus of severe encephalitis is present, consisting of a nodular aggregate of densely packed glial cells and macrophages. Atlantic salmon smolt, myelencephalon, medulla oblongata. Hematoxylin, eosin, and luxol fast blue. Scale bar $=100 \mu \mathrm{m}$ 

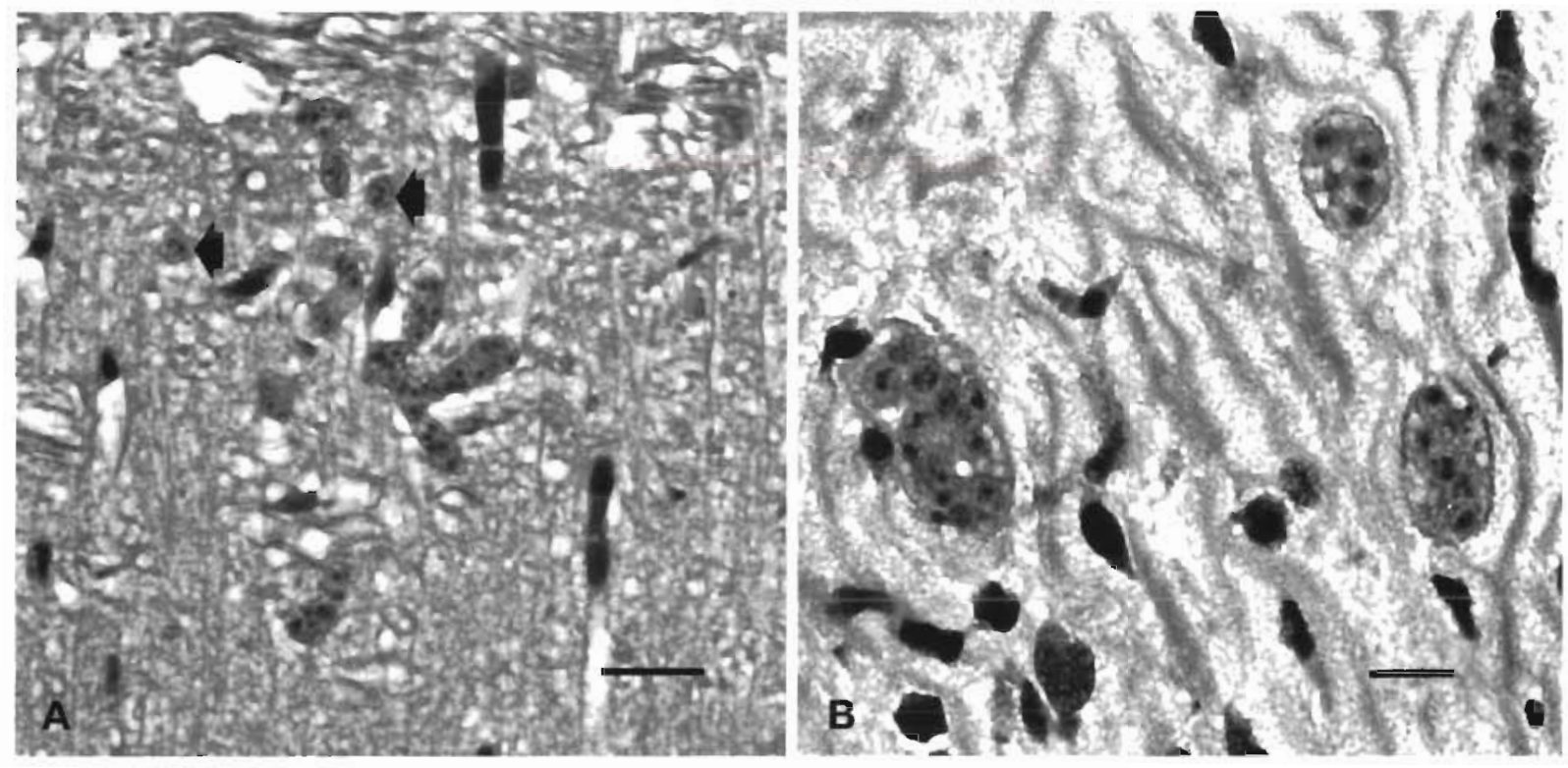

Fig. 2. Salmo salar. Multicellular developmental stages of the parasite in histologic sections of neuropil. (A) A longitudinal section of the parasite is present and consists of a membrane-bound tubule with wide-angle, club-shaped branches, containing strings or clusters of cells. Several oval, transverse sections of the parasite are present in the neuropil adjacent to the longitudinal section, and each contains 2 cells (arrows). Atlantic salmon smolt, mesencephalon, optic tectum. Hematoxylin, eosin, and luxol fast blue Scale bar $=20 \mu \mathrm{m}$. (B) Transverse sections of multicellular stages in the molecular layer. Note the thin outer membrane surrounding clusters of round or oval cells with central nuclei and thin rims of eosinophulic cytoplasm. Several round glial cells with large central basophilic nuclei and scant cytoplasm are present in the neuropil surrounding sections of the parasite. Atlantic salmon smolt, metencephalon, cerebellum. Hematoxylin, eosin, and luxol fast blue. Scale bar $=10 \mu \mathrm{m}$

(Figs. 4 \& 5). The ectoplasm contained pinocytotic channels and numerous, smooth, small diameter, round or oval, membrane-bound vesicles. The endoplasm surrounded the generative cells, and possessed occasional round homogeneous lipid droplets, many mitochondria, and numerous membrane-bound structures containing flocculent osmophilic debris and interpreted as degenerate mitochondria (Ghadially 1988a) (Fig. 5). In the endoplasm of some developmental stages were round membrane-bound structures containing stacks of membranes, similar to myelinojd bodies (Ghadially 1988b) (Fig. 3). Vegetative nuclei of the primary cell were not encountered.

Within the endoplasm of developmental stages, generative cells were dispersed individually or in cell-in-cell doublets. Each doublet consisted of an outer, secondary, cell encircling an inner, tertiary, cell (Fig. 6).

Whether as individual cells or constituents of cell doublets, generative cells possessed distinct cytoplasmic and nuclear membranes. Their cytoplasm was densely packed with rosettes of glycogen, segments of rough endoplasmic reticulum, multiple mitochondria, and scattered lipid droplets (Fig 6). Mitochondria were round to oval, and cristae were oval vesicles palisaded along the inner membrane surface (Fig. 6). Nuclei were round and occupied one-third to one-half the diameter of the cell. Chromatin was either evenly dispersed, or clumped and marginated. Most nuclei contained solitary, large, round, central, osmophilic nucleoli (Figs. $3 \&$ 6); occasional nuclei contained 2 or 3 smaller, slightly eccentric, osmophilic nucleoli. Present in the perinuclear cytoplasm of few and scattered generative cells, there were clusters of 2 to 3 round structures, ranging in diameter from 150 to $200 \mathrm{~nm}$ and consisting of a central, round, electron-dense medulla surrounded by a granular, less electron-dense cortex within which multiple, circular and tubular structures were arranged (Figs. $3 \& 7$ ). These structures were presumptively interpreted as intracytoplasmic degenerative membrane fragments. Despite sequential sampling of fish from July to August and November to January, no subsequent developmental stages were detected.

\section{DISCUSSION}

\section{Distribution of parasites and encephalitis}

Parasites were detected in the optic tectum of the mesencephalon with significantly greater frequency than in the other anatomic subdivisions of the brain. Previous studies of smolts from 1993 and 1994 reported 


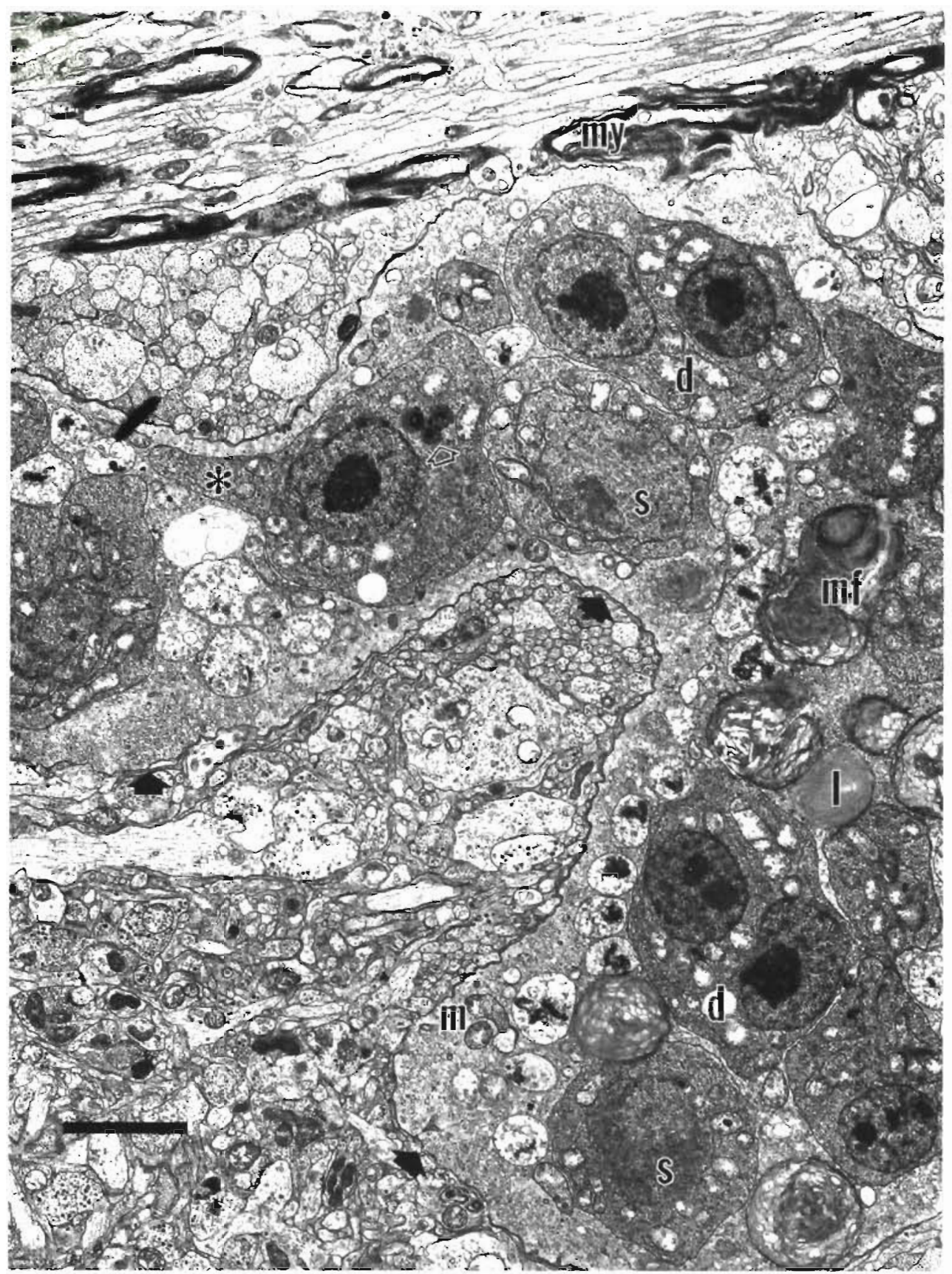

Fig. 3. Salmo salar. Transmission electron micrograph of a longitudinal section of a multicellular developmental stage of the parasite, consisting of an undulating plasmalemma (arrows) surrounding a vegetative, or pnmary, cell cytoplasm which contains multiple, closely apposed, inner, generative cells arranged in series as single cells (s) or cell doublets (d). Each cell doublet is comprised of an outer, secondary, cell which envelopes an inner, tertıary, cell. Single cells occasionally have pseudopodia-like structures $(*)$. The vegetative cell cytoplasm contauns mitochondna ( $\mathrm{m}$ ), scattered membrane-bound vacuolar inclusions containing concentric whorls of osmophilic membranous material, resembling myelınold figures (mf), and occasıonal lıpid droplets (l) Occasional cells have clusters of round osmophilic structures in the pernuclear cytoplasm (open arrow), presumptively interpreted as degenerative membrane fragments The parasite is interposed between small and medium diameter, unmyelınated, nerve fibers that are aligned along the external surface of its plasmalemma. Nerve fibers are membrane-bound and contain scattered filaments, vesicles, and occasional mitochondria Note the tract of myelnated nerve fibers (my), ensheathed in osmophilıc membranes, that course tangential to the plasmalemma of the parasite. Atlantic salmon smolt, mesencephalon, optic tectum. 


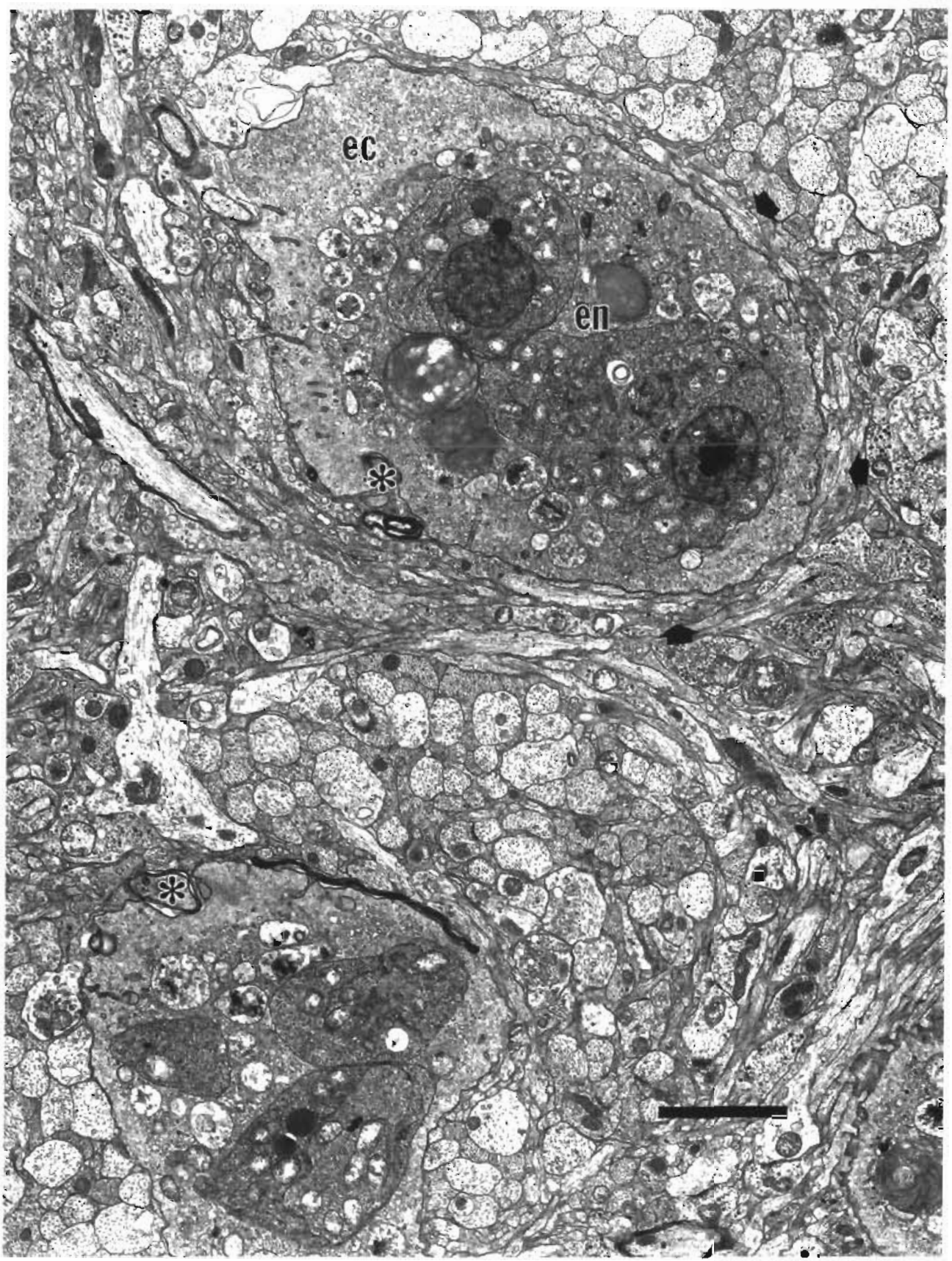

Fig 4 Salmo salar Transmission electron micrograph of transverse sections of multicellular developmental stages of the parasite interposed between nerve fibers Along the circumference of the plasmalemma of each section of the parasite, there are deep invaginations by small diameter myelınated nerve tubers (*) Compression of unmyelinated nerve fibers is evident along a segment of the plasmalemma of one of the sections of the parasite (arrows) Within developmental stages, the vegetative cell cytoplasm is separated into an outer ectoplasm (ec) and an inner endoplasm (en) laden with mitochondria, lipid droplets, and generative cells Atlantke salmon smolt. mesencephalon, optic tectum Scale bar $=1 \mu \mathrm{m}$

parasites in the cerebellum, optic tectum, and spinal cord (Rodger et al. 1995), while in this study parasites were also detected in the hypothalamus and medulla Non-random distributions of encephalotropic myxosporeans have been documented previously; polysporous plasmodia and spores of Thangula percae
Langdon, 1987 from the brain of Perca fluviatilis were detected in the white matter of the mesencephalon, diencephalon, and medulla oblongata (Langdon 1987), and plasmodia and spores of Myxobolus neurophilus were located most often in the optic tectum and occasionally in the floor of the mesencephalon or the 


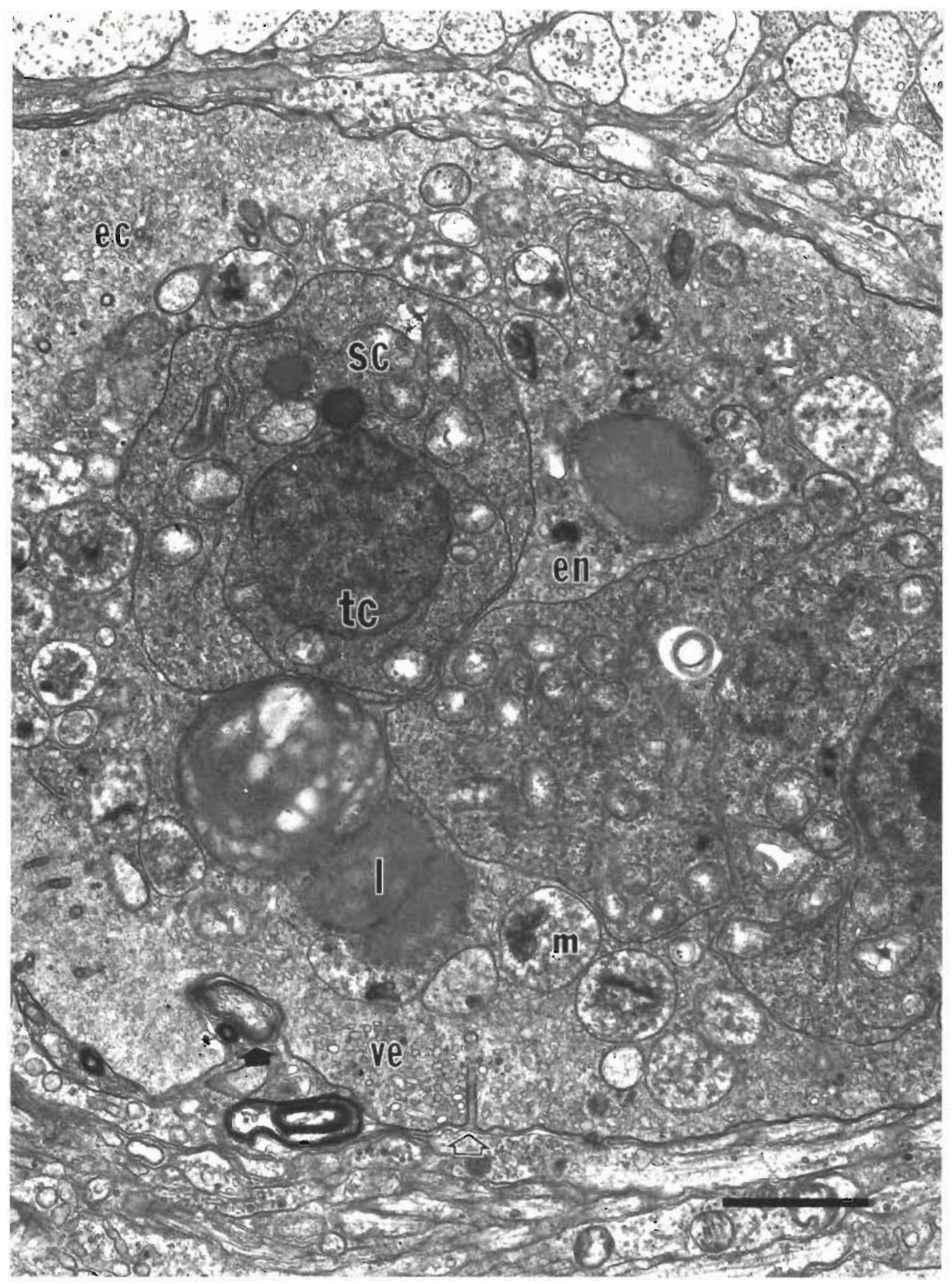

Fig. 5. Salmo salar. Transmission electron mucrograph at higher magnification of a transverse section of a multicellular developmental stage of the parasite demonstrated in Fig 4. Note the distinct separation of vegetative cytoplasm into an ectoplasm (ec) and endoplasm (en). Pinocytotic channels (open arrow) and numerous, small, round to oval vesicles (ve) are present an the ectoplasm. The endoplasm is packed with membrane-bound structures containing flocculent osmophilic debrus and unterpreted as degenerate mitochondria (m), scattered lipıd droplets (l), and generatıve cells arranged into cell doublets, each of which consısts of an outer secondary cell (sc) encircling an inner tertiary cell (tc) Note the distunct invagination of the plasmalemma by a small diameter myelinated nerve fiber (arrow). Atlantıc salmon smolt, mesencephalon, optic tectum Scale bar $=05 \mu \mathrm{m}$

leptomeninges in Perca flavescens (Dzulinsky et al. 1994). The non-random distribution of parasites reported in the present study may be related to the migratory route of the parasite through the brain.
Based on the migration of Myxobolus cerebralls via peripheral nerves and the central nervous system elucidated by El-Matboulı et al. (1995), one might speculate that the predılection for the optic tectum 


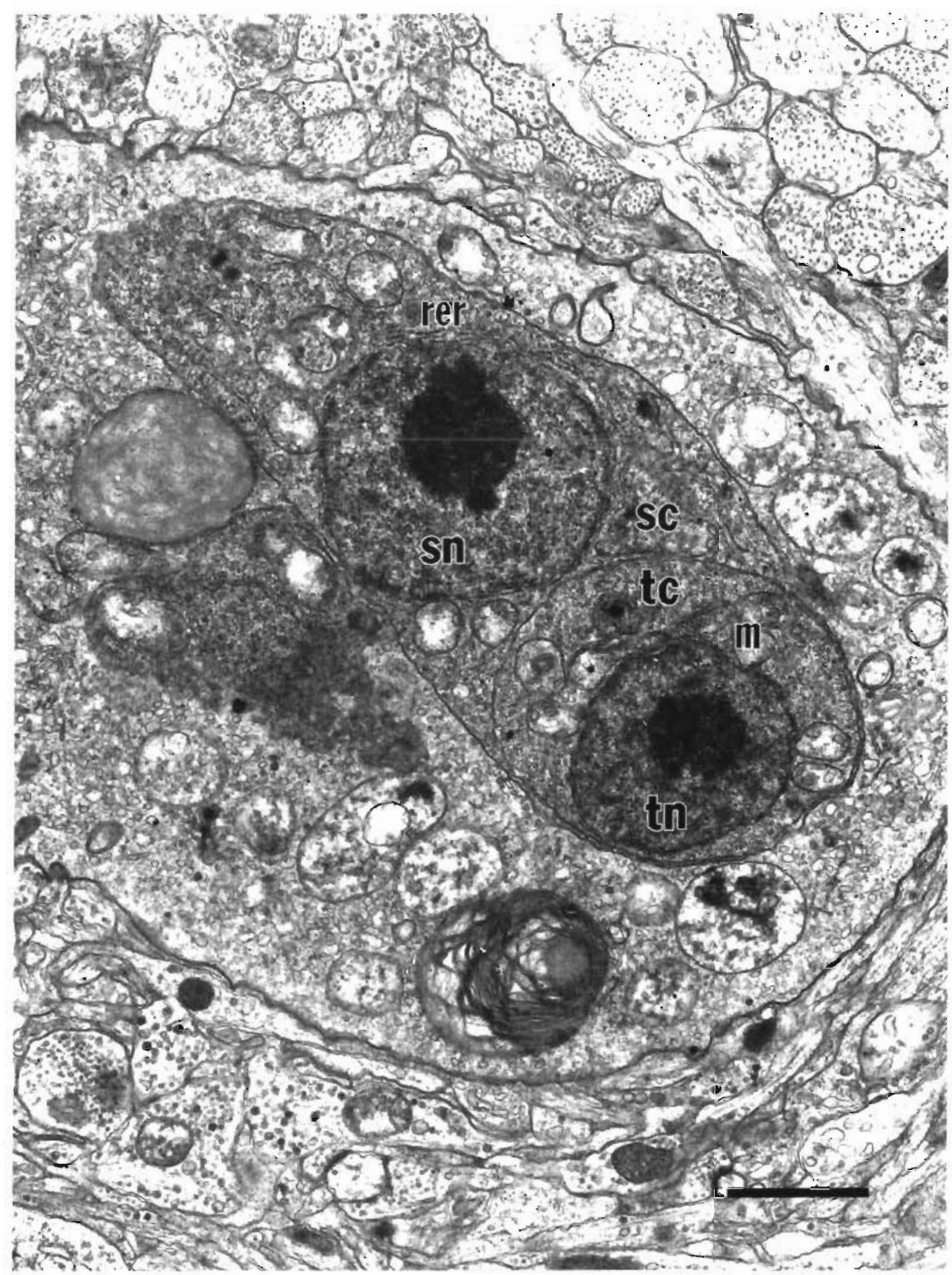

Fig 6 Salmo salar Transmission electron micrograph of cell doublet formation within the primary cell cytoplasm of a multicellular developmental stage of the parasite: Two generative cells are arranged in a cell doublet, characterized by an outer secondary cell. that envelopes an inner tertiary cell Each cell retains distinct cytoplasmic and nuclear membranes. The cytoplasm of each generative cell contains rough endoplasmic reticulum (rer), mitochondria ( $\mathrm{m}$ ), and rosettes of glycogen. Nuclei are round with marginated chromatin and solitary, round, osmophuc nucleoli. Note the similar features of the secondary cell nucleus (sn), secondary cell cytoplasm (sc) and tertiary cell nucleus (tn), tertiary cell cytoplasm (tc) Atlantic salmon smolt, mesencephalon, optic tectum Scale bar $=05 \mu \mathrm{m}$

shown by the parasite described in the present study may also be related to a migratory route along nerves. possibly involving the optic nerve. Alternatively, this non-random distribution of the parasite may be par- thally related to observational bias, since disruption of the laminar architecture of the optic tectum by stages of the parasite and inflammatory infiltrates may facilitate recognition of subtle lesions which would be less 


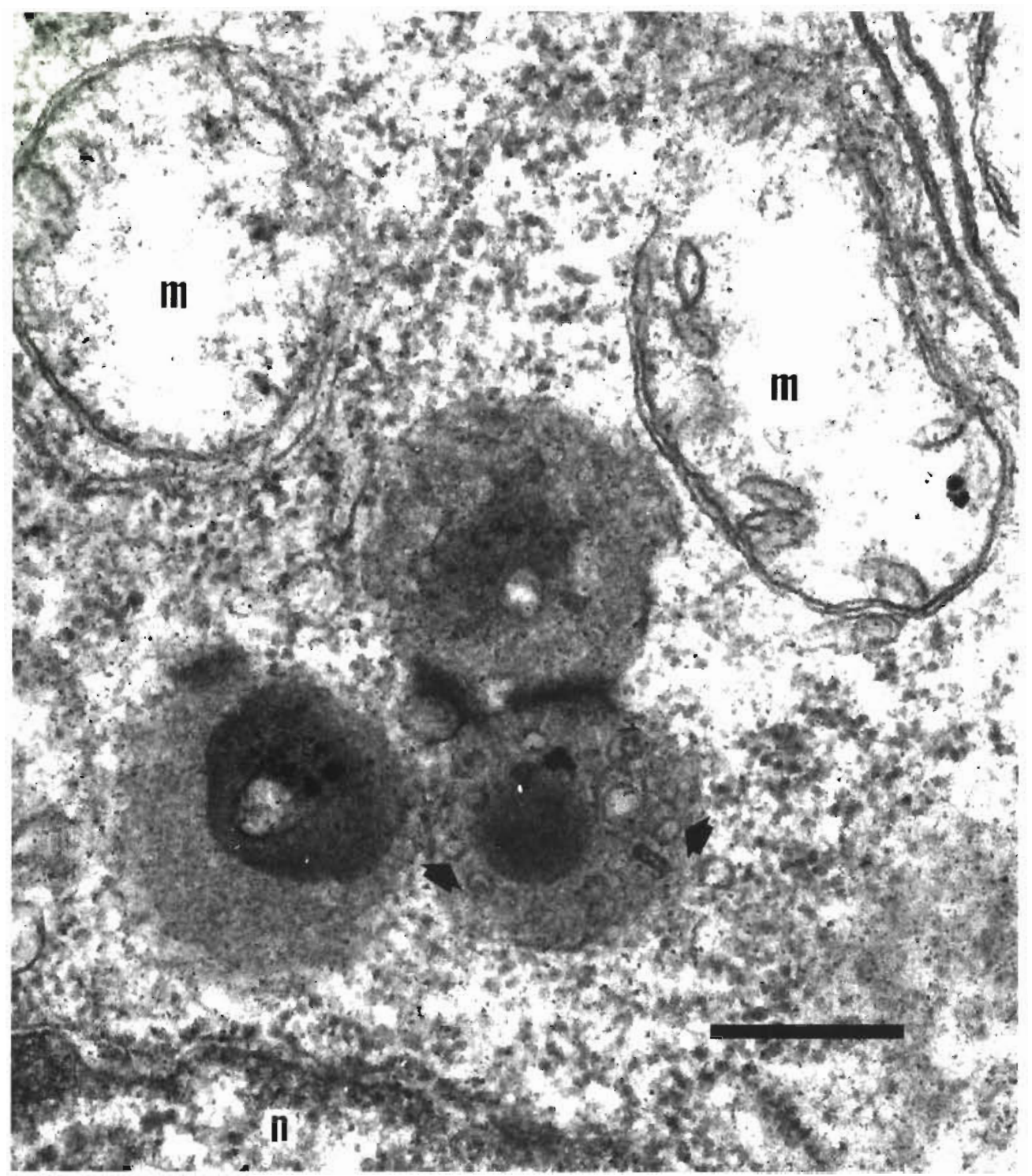

Fig. 7. Salmo salar. Transmission electron micrograph of round structures present within the pernnuclear cytoplasm of a generative cell, and presumptively interpreted as intracytoplasmic degeneratıve membrane fragments These structures consist of a densely osmophilic medullary core surrounded by a relatively le'ss osmophilic cortex, within which circular and tubular structures are arranged (arrows). Nucleus (n), mitochondria (m) Atlantıc sulmon smolt, mesencephalon, optıc tectum Scale bar $=100 \mathrm{~nm}$

easily detected in other sites. No explanations have been offered for the non-random distribution patterns of Triangula percae (Langdon 1987) or Myxobolus neurophilus (Dzulinsky et al. 1994), and no association has been made between routes of infection of the brain and sites of predilection. In fact, plasmodia of myxosporeans have been identified in blood vessels of the brain (Dykova et al. 1986), within axons (Ferguson et al. 1985), and between axons (El-Matboul et al. 1990), with no evidence of consistent regıonal predilection.

The earliest detection of parasitic developmental stages in brains occurred in smolts of the winter study from site A on Day 26 post-introduction. This time delay between introduction of smolts into the sea and brain infection is consistent with the observations of Rodger et al. (1995), and with the description by El-Matboulz et al. (1995) of the route of migration of Myxobolus cerebralis. In experimental infections of rainbow trout Oncorhynchus mykiss with tractinomyxon sporoplasms of Myxobolus cerebralis, developmental stages were detected in nearly all parts of the central nervous system and in some peripheral nerves by 4 to $24 \mathrm{~d}$ post-exposure (ElMatbouli et al. 1995) 
The distribution of encephalitis was also nonrandom, but did not correlate with that of the parasite. Foci of encephalitis were delecled with significantly greater frequency in the myelencephalon, whereas parasites were most frequently detected in the mesencephalon. This inexact correlation of distribution patterns is likely attributable to an overall failure to detect any stages other than the intercellular multicellular developmental stage reported in this or prior studies (Rodger et al. 1995, Scullion et al. 1996). Early stages, such as solitary cell doublets or primary cells containing aggregates of 2 to 4 secondary cells, were not identified in the tissue sections of brain examined in this study. It is plausible that an unknown percentage of encephalitic foci may have been initiated by earlier stages (i.e. cell doublets or small cell aggregates), which went undetected in light microscopic and ultrastructural evaluations of tissue sections. The presence of undetected early stages in anatomic subdivisions of the brain prior to the multicellular developmental parasitic stages described herein would also account for the detection of foci of encephalitis in smolts from both sites on sampling days prior to the first detection of the parasite. The earliest detection times of encephalitis in the winter study (i.e. Day 4 site A and Day 16 site C) are consistent with those reported for the detection of early stages in brains of rainbow trout experimentally infected with triactinomyxon sporoplasms of Myxobolus cerebralis. However, encephalitis did not accompany these early developmental stages of $M$. cerebralis in experimentally infected rainbow trout (El-Matbouli et al. 1995).

An alternative explanation of the discrepancy of distribution patterns of parasites and encephalitis and of the observation of encephalitis prior to the detection of multicellular developmental stages would be concurrent infection by another agent. Although a minority of smolts from the winter study had histologic lesions consistent with phagocytolytic syndrome (Palmer et al. 1992), nervous tissue is reportedly unaffected in phagocytolytic syndrome (Palmer et al. 1992), and no pathogens were detected during routine monitoring of the populations during the periods of the study.

\section{Morphology and ultrastructure of the parasite}

Based on transmission electron microscopy, the parasite is a histozoic presporogonic multicellular developmental stage of a myxosporean, with numerous inner generative cells arranged individually or in cell doublets. The cell-in-cell arrangement of the cell doublets is a characteristic feature of myxosporeans, and one of the most important and distinctive features of myxosporean development (Lom 1987). No stages of sporogony were detected in sections of infected brains. In light of the absence of sporogonic stages detectable concunently with developmental stages, we authors prefer the term presporogonic, rather than extrasporogonic (Lom 1987).

The presporogonic developmental stages observed in this study were intercellular, and their morphologic features are consistent with those described in large histozoic plasmodia, such as distinct cortical zones of pinocytotic channels, separation of cytoplasm into ectoplasm and endoplasm, relatively large numbers of generative cells, and cell doublet formation (Lom \& Dykova 1992). The genus Myxobolus forms such large histozoic polysporic plasmodia, which are preceded by histozoic presporogonic developmental stages (Lom \& Dykova 1992); however, other myxosporean genera, such as Myxidium, Henneguya, Thelohanellus, Neothelohanellus, and Trigonosporus, are also characterized by large histozoic polysporic plasmodia (Lom \& Dykova 1992). In addition to Myxobolus, 3 of these other genera have representatives that are neurotropic, although species of Thelohanellus and Neothelohanellus have been identified in brains of non-salmonid hosts, and Henneguya cerebralis has been identified in Thymallus arcticus nigrescens in Mongolia (Lom \& Dykova 1992).

The morphology of cell doublets results from endogenous cell division of secondary cells in the cytoplasm of primary cells in the cases of both presporogonic and extrasporogonic developmental stages (Lom 1987). Because cell-in-cell arrangement is an inherent feature of myxosporean life stages and is the arrangement from which the organizations of both the presporogonic and extrasporogonic cycles are derived (Lom 1987. Lom \& Dykova 1992), it is difficult to determine the developmental stage of the parasite detected in this study based solely on the morphology of the cell doublets.

No subsequent stages of sporogony were detected in any of the brains examined in this study. The absence of mature spores in the developmental stages examined does not preclude their interpretation as being presporogonic in light of the fact that only one age-class of the host was examined (i.e. smolts). In some histozoic plasmodia sporogony is synchronous all spores mature at the same time, and early and advanced stages of sporogony do not occur simultaneously (Lom \& Dykova 1992). Therefore, later stages of sporogony with mature spore formation may occur in older fish, such as those approaching maturity. No salmon from these older age-classes were sampled in this or any other studies of this parasite (Rodger et al. 1995, Scullion et al. 1996). In the present study, introductions and samplings were designed to coincide with both scheduled management practices of the sea- 
farm and previously described patterns of disease occurrence, which had been detected only in the time shortly after transfer to sea (Rodger et al. 1995, Scullion et al. 1996)

To date, this parasite has been detected only in the neuropil of the spinal cord and brain; Rodger et al. (1995) reported no significant pathology, no plasmodia, and no other parasitic stages in any other organs sampled from smolts in 1993 and 1994. Some species of the genus Myxobolus are specific to particular tissues of certain hosts, while others infect various tissues of many hosts (Lom \& Dykova 1992). A number of Myxobolus species are specific to the brain and spinal cord, and in the cases of $M$. arcticus (Pugachev \& Khokhlov 1979), M. kisutchi (Yasutake \& Wood 1957), M. neurobius (Gonzales-Lanza \& Alvarez-Pellitero 1984), M. hendricksoni (Mitchell et al. 1985), M. neurophilus (Dzulinsky et al. 1994), and $M$. cotti (Lom et al. 1989, El-Matbouli et al. 1990), plasmodia and aggregates of spores or spores alone were detected in brain and spinal cord only, and no parasitic stages were detected in other organs. In addition, some species of Myxobolus multiply only in nervous tissue before reaching the target tissue for sporogony; El-Matbouli et al. (1995) demonstrated that penetrated triactinomyxon sporoplasms of $M$. cerebralis migrate exclusively in peripheral nerves and central nervous system en route to the head cartilage, and not via blood, lymph, or coelomic fluid. Of these neurotropic myxobolids, $M$. cerebralis has been reported in Salmo salar from Europe (El-Matbouli et al. 1992), M. neurobius has been reported in Salmo trutta m. fario, Thymallus thymallus from Spain (Gonzales-Lanza \& AlvarezPellitero 1984, Lom \& Dykova 1992), and $M$. cotti has been reported in Cottus gobio from southern England (Lom et al. 1989).

Unlike the development of presporogonic and sporogonic stages in these neurotropic species of Myxobolus, other myxosporean genera, such as Sphaerospora, have proliferative extrasporogonic phases of their life cycle that occur prior to and concurrent with sporogonic phases, and are located in organs different from those of the sporogonic phase (Lom 1987, Lom \& Dykova 1992). In the case of Sphaerospora renicola, for example, the extrasporogonic stages develop in the blood and swim bladder of the common carp Cyprinus carpio and are responsible for swim bladder inflammation, while the sporogonic stage occurs in the lumina of renal tubules (Molnar 1984).

Based on the ultrastructure of the parasite, the absence of mature spores in any host organ, and the detection of the parasite in the brain and spinal cord only, the parasite is most probably a presporogonic developmental stage of a neurotropic species of myxosporean, possibly a Myxobolus species. An alternative interpretation is that the parasite is an extrasporogonic stage of a species of myxosporean with a vascular developmental stage and visceral sporogonic stage that have both not yet been detected.

\section{Epizootiology and life cycle}

Prevalences of parasites and encephalitis were significantly greater at site $\mathrm{A}$ than site $\mathrm{C}$ in the winter study, and prevalences of both were greater at site $C$ in the summer compared to the winter. In addition, smolts from both summer and winter and from sites $\mathrm{A}$ and $\mathrm{C}$ were infected with the parasite, but did not develop neurologic clinical signs. Variations in the severity of neurologic clinical signs and mortality by site, season, and year, reported by Scullion et al. (1996) and Rodger et al. (1995) and confirmed by the present study, may have been the result of complex interactions between large numbers of susceptible smolts, tidal currents affecting dispersion of infective parasitic stages, and seasonal water temperature variations. Neurologic clinical signs and mortality associated with this parasitic encephalitis probably result from high prevalence and density of the parasite, and are more likely to be associated with higher water temperatures, in which rates of myxosporean development have been demonstrated to be more rapid (El-Matbouli et al. 1992).

Identification of the parasite as a presporogonic developmental stage of a myxosporean gives insight into one possible description of its life cycle. Wolf \& Markiw (1984) and El-Matbouli \& Hoffmann (1989) demonstrated that Myxobolus cerebralis has a 2-host life cycle, alternating between actinosporean stages in a tubificid oligochaete and myxosporean stages in salmonid fishes. Since these discoveries, some 14 myxosporean species have been shown to undergo, or evidence strongly suggests that they undergo, this alternation of hosts in their life cycle (Kent et al. 1994). Based on those data detailing an alternation of actinosporean and myxosporean stages in the life cycles of some myxosporeans, we speculate that an oligochaete may be an intermediate host in the life cycle of the myxosporean infecting the brains of salmon smolts in this study.

Identification of this parasite as the presporogonic developmental stage of a myxosporean raises questions regarding the maturation of the parasite in older age classes of salmon and the role of possible intermediate hosts in the prevalence and density of infection in aquaculture scenarios. The recognition that this parasite is a proliferative stage of a myxosporean focuses future studies on its specific identity, its life cycle, and the development of preventive strategies. 
Acknowledgements. The assistance of the technical manager and staff of the fish farm is gratefully acknowledged. The authors extend their appreciation to Julie Wen and Violette Han of the Electron Microscopy Laboratory, Department of Pathology, University of Texas Medical Branch at Galveston, for their technical assistance with the transmission electron microscopy. The assistance of Robert Vrecenak and Lynn Sweet of the Interlibrary Loan Office, Homer Babbidge Library, University of Connecticut, is acknowledged, as is that of Alex Bothell of the Center for Instructional Media and Technology, University of Connecticut. This research was partially funded by grants from the Storrs Agricultural Experiment Station, College of Agriculture and Natural Resources, University of Connecticut, and from a private aquaculture company in Ireland. This manuscript is recorded as Scientific Contribution $\# 1770$ by the Storrs Agricultural Experiment Station.

\section{LITERATURE CITED}

Brown KS (1996) Veterinary biotechnology. The Scientist 10 (16): $1-9$

Carson F (1987) Nerve tissue. In: Sheehan DC, Hrapchak BB (eds) Theory and practice of histotechnology, 2nd edn. Battelle Press, Columbus, Ohio, p 252-266

Dykova I (1995) Phylum Microspora. In: Woo PTK (ed) Fish diseases and disorders, Vol 1. Protozoan and metazoan infections. CAB International, Cambridge, p 149-179

Dykova I, Lom J, Cirkovic M (1986) Brain myxoboliasis of common carp (Cyprinus carpio) due to Myxobolus encephalicus. Bull Eur Assoc Fish Pathol 6:10-11

Dzulinsky K, Cone DK, Faulkner GT, Cusack R (1994) Development of Myxobolus neurophilus (Guilford, 1963) (Myxosporea) in the brain of yellow perch (Perca flavescens) in Vinegar Lake, Nova Scotia. Can J Zool 72:1180-1185

El-Matbouli M, Fischer-Scherl T, Hoffmann RW (1990) Light and electron microscopic studies on Myxobolus cotti El-Matbouli and Hoffmann, 1987 infecting the central nervous system of the bullhead (Cottus gobio). Parasitol Res 76:219-227

El-Matbouli M, Fischer-Scherl T, Hoffmann RW (1992) Present knowledge on the life cycle, taxonomy, pathology, and therapy of some Myxosporea spp. important for freshwater fish. Annu Rev Fish Dis, p 367-402

El-Matbouli M, Hoffmann RW (1989) Experimental transmission of two Myxobolus spp. developing bisporogeny via tubificid worms. Parasitol Res 75:461-464

El-Matbouli M, Hoffmann RW, Mandok C (1995) Light and electron microscopic observations on the route of the triactinomyxon-sporoplasm of Myxobolus cerebralis from epidermis into rainbow trout cartilage. J Fish Biol 46 : 919-935

Ferguson HW, Lom J, Smith I (1985) Intra-axonal parasites in the fish Notropis cornutus (Mitchill). Vet Pathol 22: $194-196$

Ghadially FN (1988a) Ultrastructural pathology of the cell and matrix: a text and atlas of physiological and pathological alterations in the fine structure of cellular and extracellular components, Vol 1, 3rd edn. Butterworths, London, p $191-328$

Ghadially FN (1988b) Ultrastructural pathology of the cell and matrix: a text and atlas of physiological and pathological alterations in the fine structure of cellular and extracellular components, Vol 2, 3rd edn. Butterworths, London, p $589-765$

Gonzales-Lanza C, Alvarez-Pellitero P (1984) Myxobolus farionis n.sp. and M. ibericus n.sp. of Salmo trutta m. fario from the Duero basin (NW Spain). Description and population dynamics. Angew Parasitol 25:181-189

Groman DB (1982) Histology of the striped bass. American Fisheries Society Monograph No. 3. American Fisheries Society, Bethesda, Maryland, p 69-79

Hedrick RP, Friedman CS, Modin J (1989) Systemic infection in Atlantic salmon Salmo salar with a Dermocystjdiumlike species. Dis Aquat Org 7:171-177

Kent ML, Margolis L, Corliss JO (1994) The demise of a class of protists: taxonomic and nomenclatural revisions proposed for the protist phylum Myxozoa Grasse, 1970. Can J Zool 72:932-937

Langdon S (1987) Spinal curvatures and an encephalotropic myxosporean, Triangula percae sp. nov. (Myxozoa: Ortholineidae), enzootic in redfin perch, Perca fluviatilis L., in Australia. J Fish Dis 10:425-434

Lom J (1987) Myxosporea: a new look at long-known parasites of fish. Parasitol Today 3:327-332

Lom J, Arthur JR (1989) A guideline for the preparation of species descriptions in Myxosporea. J Fish Dis 12:151-156

Lom J, Dykova I (1992) Protozoan parasites of fishes. Elsevier Science Publishers B.V., Amsterdam, p 125-235

Lom J, Dykova I (1995) Myxosporea (Phylum Myxozod). In: Woo PTK (ed) Fish diseases and disorders, Vol 1. Protozoan and metazoan infections. CAB International, Cambridge, p 97-148

Lom J, Feist SW, Dykova I, Kepr T (1989) Brain myxoboliasis of bullhead, Cottus gobio L., due to Myxobolus jiroveci sp. nov.: light and electron microscope observations. J Fish Dis $12: 15-27$

Maloney R, Cawthorn RJ, Markiw M, Groman D (1991) The occurrence of Myxobolus neurobius (Myxosporea) in wild young Atlantic salmon and Atlantic char in Newfoundland. J Aquat Anim Health 3:146-147

Margolis L, Esch GW, Holmes JC, Kuris AM, Schad GA (1982) The use of ecological terms in parasitology (report of an ad hoc committee of the American Society of Parasitologists) J Parasitol 68(1):131-133

McVicar AH, Wootten R (1980) Disease in farmed juvenile Atlantic salmon caused by Dermocystidium sp. In: Ahne $W$ (ed) Fish diseases. Third COPRAQ-Session. SpringerVerlag, Berlin, p 165-173

Mitchell LG, Seymour CL, Gamble JM (1985) Light and electron microscopy of Myxobolus hendricksoni sp. nov. (Myxozoa: Myxobolidae) infecting the brain of the fathead minnow, Pimephales promelas Rafinesque. J Fish Dis 8: $75-89$

Molnar K (1984) Experimental evidence that protozoans causing swim-bladder inflammation in common carp (Cyprinus carpio L.) are stages of Sphaerospora renicola. Bull Eur Assoc Fish Pathol 4:14-15

Moser M, Kent ML (1.994) Myxosporea. In: Kreier JP (ed) Parasitic protozoa, Vol 8. 2nd edn. Academic Press, San Diego, CA, p 265-318

Palmer R, Soutar RH, Branson EJ, Southgate PJ, Drinan E, Richards RH, Collins RO (1992) Mortalities in Atlantic salmon, Salmo salar $L_{\text {., }}$ assocjated with pathology of the melano-macrophage and haemopoietic systems. J Fish Dis 15:207-210

Pugachev ON, Khokhlov PP (1979) Myxosporidia of the genus Myxobolus-parasites of brain and spinal cord of salmonids (in Russian). Sistematika i ekologia ryb kontinentalnykh vodoemov Dalnego Vostoka, Braduboctok, p 137-139

Rodger HD. Turnbull T, Scullion FT, Sparrow D, Richards RH (1995) Nervous mortality syndrome in farmed Atlantic salmon. Vet Rec 137:616-617 
Rutherford DT, Wood CC, Hyatt KD, Margolis L, McDonald TE, Riddell BE, Whithler RE (1992) Biological characteristics of coastal populations of sockeye salmon (Oncorhynchus nerka) in British Columbia. Can Tech Rep Fish Aquat Sci No. 1849

Scullion FT, Scullion MG, Sparrow D, Rodger HD, Sheahan BJ (1996) Encephalitis and mass mortality of farmed salmon smolts in an isolated sea bay in Ireland. Vet Rec 138:161-162

Wolf K, Markiw HE (1984) Biology contravenes taxonomy in the Myxozoa: new discoveries show alternation of

Editorial responsibility: Wolfgang Körting,

Hannover, Germany invertebrate and vertebrate hosts. Science 225:1449-1452 Wyatt EJ (1978) A new host and site of infection for Myxobolus kisutchi and host record for Myxobolus insidiosus. J Parasitol 64\{1\}:169-170

Yasutake WT, Wales JH (1983) Microscopic anatomy of salmonids: an atlas, United States Department of the Interior, Fish and Wildlife Service, Resource Publication 150. United States Department of the Interior. Fish and Wildlife Service, Washington, DC, p 104-117

Yasutake WT, Wood EM (1957) Some myxosporidia found in Pacific Northwest salmonids. J Parasitol 43:633-642

Submitted: October 22, 1997; Accepted: February 2, 1998 Proofs received from author(s): March 23, 1998 